\title{
The Analysis of Active Learning Practices in Pre-Service Teacher Training and Education
}

\author{
$1^{\text {st }}$ Pratiwi, Essy \\ Dept of Magister Science \\ Education \\ Sebelas Maret University \\ Indonesia \\ essydian060@student.uns.ac.id
}

\author{
$2^{\text {nd }}$ Masykuri, Mohhamad \\ Dept of Chemistry Teacher \\ Education \\ Sebelas Maret University, \\ Indonesia \\ mmasykuri@yahoo.com
}

\author{
$3^{\text {rd }}$ Ramli, Murni \\ Dept of Biology Teacher \\ Education \\ Sebelas Maret University, \\ Indonesia \\ mramlim@staff.uns.ac.id
}

\begin{abstract}
Active learning in higher education can be defined as a process to provide pupils with more opportunities to optimize their understanding by experiencing various learning process especially to teacher candidate program. This research is a classroom observation aims to analyze the active learning (AL) practices in higher education and to know how the lecturer and students play roles in learning process. The participants were five lecturers of Biology Education Department, and one lecturer of Chemistry Education Department. There were six courses observed: Health and Nutrition Sciences, Biotechnology, English for Biology, Scientific Method, Environment Chemistry, and Animals Anatomy. The lecturers participated voluntarily. The data of $A L$ practices at the classroom was gathered used TDOP (Teaching Dimension Observation Protocol). The instrument used to know the pattern of the interval that can be shown on practice of AL. There are five components of TDOP, i.e. instructional practices; studentteacher dialog; instructional technology; potential student cognitive engagement; and pedagogical strategy. Data was recorded in 10 intervals every two minutes. The result indicates for ten intervals, the dominant form that showed on learning process in science education is the teachers focused instruction $(68.5 \%)$ and teacher-led dialog (46.17\%). For student-focused instruction $(44 \%)$ and student-led dialog $(44 \%)$. The technologies particularly used during lecturing is the power point $(42.33 \%)$, movie $(3.33 \%)$, and whiteboards $(1.67 \%)$. Based on this study, an interval of time has to be considered and the number of science classes from other department to be observed should be extended. The findings suggest some implications and limitations make a further research about similar research.
\end{abstract}

Keywords-Active learning (AL); Higher Education; Science Education; Pre Service Teacher

\section{INTRODUCTION}

Learning at higher education has distinct characteristics from learning in middle or high school because of students' age differences define the maturity of thinking skills. Also, because the subject matters in higher education are more complex and abstract. In higher education, the opportunity for students to get knowledge and skills need to be promoted, with integrating the classroom lectures with real-life practices with various learning experiences. To make sure the quality of the graduate, education practices in higher educations must provide knowledge and skill Acquisition based on the existing field of discipline [1, 2].

Students' involvement in learning process has positive effects on their development progress [3]. Students' activities in classrooms can be used as the instrument to assess the learning outcomes [4]. Students are interested in learning if the class becomes more active, and concepts delivery not only from teachers' monologs [5]. Changes in learning rhetoric as the improvement to the learning process in higher education help students to face learning difficulties [6].

Active learning is explain as any strategy that bring and make student in doing things and involve them in thinking what they are doing [7]. AL gives the opportunity to students to find out the concepts and build their own understanding. In verse, students will have difficulties to build their concepts if they only become the passive receiver of information [8]. Active learning in the classroom involves the students to improve their understanding and help to connect the gained knowledge with reality [9]. For next AL becomes important in higher educations because, after graduation, the graduate will enter the workforce and have to build their careers [10].

Implementation of the AL has been reported of some research [11-13]. It helps to depict the need for active-students-centered learning in higher education has become widespread. One of effect is the implementation of AL model can increase pre service teachers' ability [14].That is, higher education should be focus on enhancing quality of teacher education programs especially in science education so that the teachers candidate had achieve capable skill in society. 
Active learning for pre-service teacher education program is important. It can be used by the students as the references how to carry out the active learning when they become the teachers. AL practices in preservice teacher education program bring positive effects for improvement of pre-service teacher knowledge and skills. Research on the practices of $\mathrm{AL}$ in pre-service teacher education has been conducted in some countries [15-17].

We must do lectures mapping, to find out the practices and implementation of the AL in pre-service teacher educations in Indonesia. This research aimed to map out and analyze the lecture patterns in the Faculty of Education and Teacher Training, Sebelas Maret University, on the departments train the preservice teachers in the biology, the physic, the chemistry, and general natural science.

Lectures learning process analysis were done by several researchers to find out the interaction patterns between students and lecturers and students with the student. Also to find out how the knowledge transfer process occurred in the classes. One of the common methods is the TDOP (Teaching Dimension Observation Protocol) and the ROTP (Reformed Teaching Observation Protocol). The TDOP was introduced by Matthew Hora [18] funded by NSF funded study of the cognitive, cultural, and contextual underpinnings of post-secondary teaching practice. While the RTOP was first introduced by Daiyo Sawada and Michael Piburn from the Evaluation Facilitation Group (EFG) of the Arizona Collaborative for Excellence in the Preparation of Teachers (ACEPT), and it is an observational instrument designed to measure "reformed" teaching [19].

The RTOP and the TDOP are the classroom observation instruments designed to observe learning activities and interactions occurred between the teachers and students. This is an open instrument and can be extended so the researcher can develop more codes based on the observed phenomena from learning activities in the class. The TDOP is different from the RTOP. The TDOP is an interval-type instrument for two minutes observation intervals. While the RTOP is a holistic instrument for all learning periods. Reviews about the usage of the TDOP have been conducted by Hora [20] and Macissac [21] for the RTOP.

The researcher opted to use the TDOP. The TDOP used to find out the interaction and students' involvement in learning activities. It important note, the codes cannot depict the consistency of some aspects in the interactive learning but can be used as the indicator for interactive learning [22]. Observing students' activities and active involvement are the method of data collection [23].

Based on those descriptions, this research aimed to answer the questions below:

1. How about the learning practices in Department of Science Education, Faculty of Teacher
Training and Education, Sebelas Maret University?

2. How the lecturer and students play roles in learning process?

3. Is the learning process has depicted the Active Learning practices?

\section{METHOD}

Observation is especially useful things in investigating where study with participants has limited information [24]. This research was a classroom observation aimed to analyze the active learning $(\mathrm{AL})$ practices in pre-service teacher training and to know how the lecturer and students play roles in learning process. The observation was by 2 observers. The participants were five lecturers of Biology Education Department, and one lecturer of Chemistry Education Department (Table 1). There were six courses observed: Health and Nutrition Sciences, Biotechnology, English for Biology, Scientific Method, Environment Chemistry, and Animals Anatomy. All classes were observed. This observation conducted just one meeting for each department (a learning period equal to 50 minutes). Data were recorded into two-minute intervals. The lecturers were selected purposively and asked to participate voluntarily

TABLE 1. RESPONDENT DESCRIPTIONS

\begin{tabular}{|l|c|c|}
\hline & $\begin{array}{c}\text { Participants } \\
\boldsymbol{n}\end{array}$ & Percentage \\
\hline Total & 6 & 100 \\
\hline Sex (Female) & 2 & 33 \\
\hline Sex (Male) & 4 & 67 \\
\hline Discipline (Biology) & 5 & 83 \\
\hline Discipline (Chemistry) & 1 & 17 \\
\hline Size of course (25 or less) & 1 & 17 \\
\hline Size of course (26 - 100) & 5 & 83 \\
\hline Lecturer/Instruction & 6 & 100 \\
\hline
\end{tabular}

The data of $\mathrm{AL}$ practices at the classroom was analyzed based on the TDOP (Teaching Dimension Observation Protocol) instrument by Hora Matthew (Table 2). There are five components of TDOP: instructional practices; student-teacher dialog; instructional technology; potential student cognitive engagement; and pedagogical strategy.

TABLE 2. THE TDOP CODES USED FOR LEARNING INTERACTIONS

\begin{tabular}{|c|c|c|}
\hline Categories & The Codes & Description \\
\hline $\begin{array}{l}\text { Instructional } \\
\text { practice } \\
\text { (Teacher- } \\
\text { focused } \\
\text { instruction) }\end{array}$ & $\begin{array}{c}\text { L, LW, LVIS, } \\
\text { LDEM, SOC- } \\
\text { L, WP, IND, } \\
\text { IL, MM, A, } \\
\text { AT }\end{array}$ & $\begin{array}{l}\text { Refers to the lecturers as the } \\
\text { main actors }\end{array}$ \\
\hline $\begin{array}{l}\text { Instructional } \\
\text { practice } \\
\text { (Student- } \\
\text { focused } \\
\text { instruction) }\end{array}$ & SGW, DW, SP & $\begin{array}{l}\text { Refers to the lecturers as the } \\
\text { main actors }\end{array}$ \\
\hline $\begin{array}{l}\text { Student } \\
\text { teacher }\end{array}$ & $\begin{array}{l}\text { IRQ, IDQ, } \\
\text { ICQ }\end{array}$ & $\begin{array}{l}\text { Dialogs (Lecturers' questions } \\
\text { responded by the students) }\end{array}$ \\
\hline
\end{tabular}




\begin{tabular}{|c|c|c|c|}
\hline \multicolumn{3}{|c|}{ Indicators } & Cohen Kappa \\
\hline \multicolumn{3}{|c|}{$\begin{array}{l}\text { Instructional Practice (Teacher focused } \\
\text { instruction) }\end{array}$} & 0.8259 \\
\hline \multicolumn{3}{|c|}{$\begin{array}{l}\text { Instructional Practice (Student focused } \\
\text { instruction) }\end{array}$} & 0.544 \\
\hline \multicolumn{3}{|c|}{$\begin{array}{l}\text { Student Teacher Dialog } \\
\text { led dialog) }\end{array}$} & 0.8571 \\
\hline \multicolumn{3}{|c|}{$\begin{array}{l}\text { Student Teacher Dialog } \\
\text { led dialog) }\end{array}$} & 0.8201 \\
\hline \multicolumn{3}{|c|}{ Instructional Technology } & 0.8901 \\
\hline \multicolumn{3}{|c|}{ Pedagogical strategies } & 0.4827 \\
\hline \multicolumn{4}{|l|}{$\begin{array}{l}\text { dialog } \\
\text { (Teacher-led } \\
\text { dialog) }\end{array}$} \\
\hline $\begin{array}{l}\text { Student } \\
\text { teacher } \\
\text { dialog } \\
\text { (Student-led } \\
\text { dialog) }\end{array}$ & SQ, SR, PI & \multicolumn{2}{|c|}{$\begin{array}{c}\text { Dialogs (Students' responses } \\
\text { or questions from the } \\
\text { students) }\end{array}$} \\
\hline $\begin{array}{l}\text { Instructional } \\
\text { Technology }\end{array}$ & $\begin{array}{l}\text { CB, OP, PP, } \\
\text { CL, D, DT, M, } \\
\text { SI, WEB }\end{array}$ & \multicolumn{2}{|c|}{$\begin{array}{l}\text { Refers to the technology } \\
\text { usage in learning activities }\end{array}$} \\
\hline $\begin{array}{l}\text { Potential } \\
\text { Student } \\
\text { Cognitive } \\
\text { Engagement }\end{array}$ & CNL, PS, CR & \multicolumn{2}{|c|}{$\begin{array}{l}\text { Refers to the lecturers train } \\
\text { skills to the students. }\end{array}$} \\
\hline $\begin{array}{l}\text { Pedagogical } \\
\text { strategies }\end{array}$ & $\begin{array}{l}\text { HUM, ORG, } \\
\text { EMP }\end{array}$ & \multicolumn{2}{|c|}{$\begin{array}{l}\text { Refers to the way lecturers } \\
\text { deliver the matters }\end{array}$} \\
\hline
\end{tabular}

\section{RESULTS AND DISCUSSION}

\section{A. Analysis of the Lectures Learning Activities}

Figure 1 showed the results of the lectures activities mapping from six lecturers of the biology education and chemistry education program. The $\mathrm{X}$-axis showed the indicators appeared in the observations: teachers-focused instruction; studentsfocused instruction; teacher-led dialog; student-led dialog; instructional technology; and pedagogical technology. The $\mathrm{Y}$-axis showed the score acquisitions (\%) for each indicator. It can be seen the teacher focused instruction dominating others. Results from observations can be used to scan out the learning activities [25].

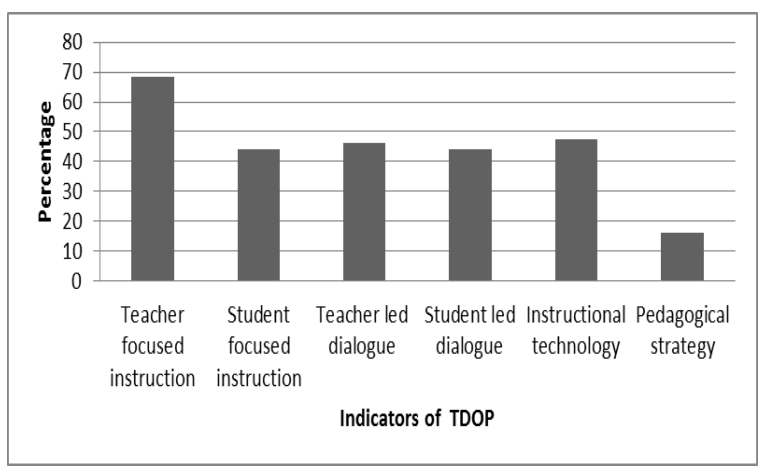

Fig 1. Scores of the indicators of learning

The Inter Rater Reliability (IRR) test was done to ensure the data accuracy. The results of the IRR test used to crosscheck the accuracy of the inter- researcher codes, so the results were accurate. The results of the IRR test were shown on the Table 3.

TABLE 3. DESCRIPTIONS OF THE
IRR

\section{B. Attempts to Implement the Active Learning}

After classroom observation with 10 intervals every two minutes, got data as followed. Teacherfocused instruction recorded as $68.5 \%$. Direct instructions were used by the lecturer in the early stage of learning. The recorded direct instruction activities were: direct instruction (L) 39.17\%; direct instruction with visual aids (LVIS) 18.5\%; direct instruction with writing (LW) $1.67 \%$; illustrating (IL) $1.67 \%$; direct instruction with questioning (SOC-L) $1.67 \%$; and instruction to individuals and groups (IND) $4.17 \%$. The IND showed the lecturers were asked the students to make small groups. Small groups were the part of active learning activities [26], because the students were expected to have interactions and learning with others, so they become more active and productive [27]. Lecture could be included lecturers' introduction their definitions, describe theories, or could supporting information The uses of direct instructions in the early stage of learning can help students to understand the concepts if followed with other interactive activities.

The student-focused instruction recorded as $44 \%$. The types of the student-focused instruction were: small group discussions (SGW) 2.67\%; doing individual works (DW) 5.83\%, and students' presentations (SP) $10.17 \%$. The most dominant student-centered activities were the students' presentation. Students centered learning have potential to support active learning. Because the students were expected to be actively doing various learning activities, not just become the passive receivers [28]. A classroom discussion could be included in active learning because it makes students to create their own opinions and discuss issues in highlight. Discussion aim to increase their level learning because students should build their own ideas and trying to understand and contribute the opinions among the other students [29].

The teacher-led dialog had bigger percentages than student-led dialog. The recorded activities for the teacher-led dialogs were: questions to obtain information (IDQ) 4.17\%; rhetoric questions (IRQ) $3.33 \%$; and questions about students' understanding (ICQ) $38.67 \%$. The recorded student-led dialogs were: students' responses (SR) $41.33 \%$; and peer-topeer interactions (PI) 2.67\%. The percentages of students' responses were in line with the lecturers' question about understanding and question to get information. Questioning in learning process was the attempt of the active learning implementation [30]. The questions should be improved into questions stimulate the students' thinking skill to improve students' understanding. 
The recorded instructional technology usages were: the whiteboards (CB) $1.67 \%$; the PowerPoint presentations (PP) 42.33\%; film, documentary, and YouTube videos (M) 3.33\%. The PowerPoint presentation was dominating because it was the most workable media for lecturers and because the LCD projectors were widely available in the classroom. The media become more various and involve the students in learning, its better.

The recorded pedagogical strategies were: humor (HUM) $12.83 \%$ and attention (3.33\%). This Indicator was optional. We choose to use it to find out pedagogical strategies other than existing learning methods and techniques. It refers to behavioral pedagogy by Harry Murray [31].

Lecturers' and students' involvement were important for learning activities. Lecturers have roles as the learning facilitators, and the students were expected to be active actors in the learning process. Students must develop their thinking skills.

\section{IRR Test for TDOP}

The IRR was the method to ensure reliability and quality of research data [20]. The IRR test has done using web programs. It's important to ensure the data were usable. We choose Cohen Kappa methods. It can be seen in Table 3, the value for instructional technology has the very good grade compared with pedagogical strategies (enough). The Kappa values were stable because the values were between enough to very good. The number $\neq 1$, but $\approx 1$. If the value $\approx$ 1 , means it has good consistency among the researcher. The kappa value used to analyze the data from respondents. Because in this research the observers were the respondents.

\section{CONCLUSION}

The majority of learning activities were direct instructions, the dialogs dominated by the lecturers, and the media dominated by the PowerPoint presentations. Lecturers' roles in learning activities still dominating, and students do not yet have independencies to direct the learning process. The lecturers' active learning practices net yet depicts students centered learning. Need further research to completely find out the dominant activities in the learning process, so the students centered learning will be revealed.

\section{ACKNOWLEDGEMENT}

This research is sponsored by the Grant from the Research and Community Development Institution, Sebelas Maret University 2017-2018 led by Murni Ramli

\section{REFERENCES}

[1] Bradley, D., Noonan, P., Nugent, H. \& Scales, B. (2008). Review of Australian Higher Education, Final Report. Department of Education, Employment and Workplace Relations. Canberra

[2] Kember, D. (2009). Nurturing generic capabilities through a teaching and learning environment which provides practise in their use. Higher Education, 57(1), 37-55.

[3] Keyser, M. W. (2000). Active learning and cooperative learning: Understanding the difference and using both styles effectively. Research Strategies, 17 (1), 35-44.

[4] Lee, D. Ediger, R. Hyun J. (2017). Students' Satisfaction on Their Learning Process in Active Learning and Traditional Classrooms. International Journal of Teaching and Learning in Higher Education, 29 (1), 108-118

[5] Faust, J. L., \& Paulson, D. R. (1998). Active learning in the college classroom. Journal on Excellence in College Teaching, 9 (2), 3- 24

[6] Fook, C. Y., \& Sidhu, G. K. (2014). Investigating Learning Challenges faced by Students in Higher Education. Social and Behavioral Sciences. 186 (2015) $604-612$

[7] Bonwell, C., and Eison, J. (1991), Active learning: Creating Excitement in the Classroom, ASHE-ERIC Higher Education Report No 1, George Washington University, Washington, DC

[8] Mathias, Amber. (2014). Active Learning In The Science Classroom. Honors Projects. Paper 113.

[9] Bransford JD, Brown AL, Cocking RR. 2000. How People Learn: Brain, Mind, Experience and School. Washington, D.C.: National Academy Press

[10] Naithani, P. 2008. Reference Framework for Active Learning in Higher Education. BIT International Center, Kingdom of Bahrain

[11] Tatachar, A., Li, F., Gibson et al. (2016). Pharmacy students' perception of learning and satisfaction with various active learning exercise. Currents in Pharmacy Teaching and Learning, 8 (4), 577-583

[12] Walton, A., Isaacs. A, et al. (2016). Design of drug-induced diseases elective utilizing active learning. Currents in Pharmacy Teaching and Learning, 8 (2016), 90-95

[13] Lee, J., Son. Y. (2016). Active Learning using transductive sparse Bayersian regression. Information sciences, 374, 240254.

[14] Wahidin, D., Muchtar. Hendi, et al. (2017). The Implementation of active learning model for preparing preservice teachers. GSTF Journal on Education (JED), 4 (2)

[15] Nelson, et al. (2015). Using Active-Learning Strategies to Increase Pre-Service Teachers' Efficacy in a ServiceLearning Course. International Journal of Research on Service-Learning and Community Engagement, 3 (1), 1-16

[16] Montalbano et al. (2014). Active learning in pre-service teacher education. ICPE-EPEC 2013 Proceedings

[17] Sileo, et al. (1998). Strategies to Facilitate Preservice Teachers' Active Involvement in Learning. Teacher Education and Special Education, 21 (3), 187-204.

[18] Hora, M. T. (2013). Exploring the Use of the Teaching Dimensions Observation Protocol to Develop Fine-grained Measures of Interactive Teaching in Undergraduate Science Classrooms. WCER Working Paper. Retrieved from University of Wisconsin-Madison, Wisconsin Center for Education

[19] Piburn, Michael \& Sawada, Daiyo. 2000. Reformed Teaching Observation Protocol (RTOP) Reference Manual Technical Report (Arizona State University)

[20] Hora, B. M. T., \& Ferrare, J. J. (2014). Remeasuring Postsecondary Teaching: How Singular Categories of Instruction Obscure The Multiple Dimensions of Classroom Practice. Journal of College Science Teaching , 43 (3), 36-41

[21] Macisaac, D., \& Falconer, K. (2002). Reforming physics instruction via RTOP. The Physics Teacher, 40, 479-485. 
[22] Hora, M.T., Oleson, M., \& Ferare, J. J. (2013). Teaching dimensions observation protocol (TDOP) user's manual. TDOP Wceruw

[23] Lee, O., \& Brophy, J. (1996). Motivational Patterns Observed in Sixth-Grade Science Classrooms. Journal of Research in Science Teaching, 33, 303-318

[24] Creswell, J. W. 2009. Research Design: Qualitative, Quantitative, and Mixed Methods Approaches. Thousand Oaks, CA: Sage Publishing.

[25] Pianta, R. C., \& Hamre, B. K. (2009). Conceptualization, measurement, and improvement of classroom processes: Standardized observation can leverage capacity. Educational Researcher, 38 (2), 109-119.

[26] Hora, J., Ferrare, J. (2013). Review of Classroom Observation Techniques in Postsecondary Settings. Retrieved from University of Wisconsin-Madison, Wisconsin Center for Education Research

[27] Morrison, T. 2004. Promoting Active Learning in University Classes. The Hong Kong Polytechnic University
[28] Prince, M. (2004). Does Active Learning Work? Review of the Research, 93 (July), 223-231

[29] Hadjioannou, X. (2007). Bringing the background to the foreground: What do the classroom environments that support authentic discussions look like? American Educational Research Journal, 44, 370-399

[30] Braxton, J., Milem, J., \& Sullivan, A. (2000). The Influence of Active Learning on The College Student Departure Process: Toward a Revision of Tinto's Theory Author(s). The Journal of Higher Education, 71 (5), 569

[31] Murray, H. G. (1983). Low-inference classroom teaching behaviors and student ratings of college teaching effectiveness. Journal of Educational Psychology, 75, 138149 